Journal of Southeast Asian

\title{
HMong Parent Day/Hnub Txhawb Nqa Niam Txiv: Implementing Psychosociocultural Educational Programming to Honor Rau Siab
}

Pa Her

University of Wisconsin - Madison, her1@wisc.edu

Alberta M. Gloria

University of Wisconsin-Madison, amgloria@wisc.edu

Shee Yee Chang

University of Wisconsin-Madison, tubhmoob80@gmail.com

Pahoua Thao

University of Wisconsin-Madison, pahoua8@gmail.com

Follow this and additional works at: https://docs.lib.purdue.edu/jsaaea

Part of the Bilingual, Multilingual, and Multicultural Education Commons, Multicultural Psychology Commons, and the Scholarship of Teaching and Learning Commons

\section{Recommended Citation}

Her, Pa; Gloria, Alberta M.; Chang, Shee Yee; and Thao, Pahoua (2022) "HMong Parent Day/Hnub Txhawb Nqa Niam Txiv: Implementing Psychosociocultural Educational Programming to Honor Rau Siab," Journal of Southeast Asian American Education and Advancement. Vol. 17 : Iss. 1, Article 1.

DOI: $10.7771 / 2153-8999.1239$

Available at: https://docs.lib.purdue.edu/jsaaea/vol17/iss1/1

This document has been made available through Purdue e-Pubs, a service of the Purdue University Libraries. Please contact epubs@purdue.edu for additional information.

This is an Open Access journal. This means that it uses a funding model that does not charge readers or their institutions for access. Readers may freely read, download, copy, distribute, print, search, or link to the full texts of articles. This journal is covered under the CC BY-NC-ND license. 


\section{HMong Parent Day/Hnub Txhawb Nqa Niam Txiv: Implementing Psychosociocultural Educational Programming to Honor Rau Siab}

\section{Cover Page Footnote}

Author Notes At the time of the Hmong Parent Days, Pa Her and Pahoua Thao were master's students in Counseling Psychology and Alberta M. Gloria is a professor in the Department of Counseling Psychology. Shee Yee Chang was a master's student in the Department of Educational Leadership and Policy Analysis. All authors are affiliated with the University of Wisconsin-Madison. 


\title{
JSAAEA Journal of Southeast Asian American Education and Advancement
}

Vol. 17 Iss. 1 (2022)

WWW.JSAAEA.org

\section{HMong Parent Day/ Hnub Txhawb Nqa Niam Txiv: Implementing Psychosociocultural Educational Programming to Honor Rau Siab ${ }^{1}$}

\author{
Pa Her, Alberta M. Gloria, Shee Yee Chang, and Pahoua Thao \\ University of Wisconsin-Madison
}

\begin{abstract}
This paper describes the interrelated conceptual activities that took a Psychosociocultural (PSC) approach to direct best practices, interactions, and processes to implement HMong ${ }^{2}$ Parent Days effectively. The purpose of HMong Parent Day/ Hnub Txhawb Nqa Niam Txiv, a culturally-centered communityfocused intervention, was to bring HMong parents onto a midwestern predominantly white university campus for a day of college knowledge. The day honored HMong parents' support of their children into and through higher education via the cultural value of rau siab (hard work). Three levels of learning that emerged as new knowledge for HMong parents are highlighted and discussed relative to the PSC approach. Implications for scholars and university personnel are provided. The benefits of a culturally-centered community-focused intervention are discussed.
\end{abstract}

Keywords: HMong parents, community-focused intervention, college knowledge, rau siab, Psychosociocultural

This paper discusses a culturally-centered community-focused intervention, the HMong Parent Day (HPD)/Hnub Txhawb Nqa Niam Txiv, which was designed to primarily support HMong parents and to secondarily advance and increase HMong students' presence at a predominantly white university. One way to support students from an educational and community approach is to use culturally-centered community-focused interventions that emphasize collaboration between multiple social contexts such as the community and the university in response to the needs of students (Dalton et al., 2001; Field et al., 2006). HPD exemplified one way to support HMong students by involving parents and acknowledging parental influence on their children's persistence to earn a higher education (Gloria et al., 2017). A research team sought to address the call from the community that HMong parents wanted to be included and know more about their child's education (Gloria et al., 2017; Lee \& Green, 2008; Lor, 2008). However, they indicated not feeling

\footnotetext{
(c)

SDDERIIEHISRESERNEDReaders are free to copy, display, and distribute this article, as long as the work is attributed to the author(s) and the Journal of Southeast Asian American Education \& Advancement, it is distributed for non-commercial purposes only, and no alteration or transformation is made in the work. More details of this Creative Commons license are available at http://creativecommons.org/licenses/by-nc-nd/3.0/. All other uses must be approved by the author(s) or JSAAEA.
}

Journal of Southeast Asian American Education \& Advancement, Vol. 17. Iss. 1. (2022) ISSN: 2153-8999 
welcomed or part of the university community to the extent that they assumed they did not have the right to ask for information (Gloria et al., 2017). Seeking to translate research into action for the community's benefit, the research team hosted a one-day event for HMong parents for three years at a predominantly white university. The HPD events were a specific community-focused action that involved HMong parents learning and finding empowerment with the university in a culturally relevant and honoring way.

HMong are an ethnic group whose history traces back to southern China (Lee \& Tapp, 2010), some of whom relocated to Southeast Asia due to political persecution in the late 1800s (Yang, 2003). HMong Americans are those who migrated and settled in Laos as slash-and-burn farmers with limited access to education (Lee \& Tapp, 2010; Vang \& Flores, 1999). The CIA recruited them to fight during the Vietnam War (Lee \& Tapp, 2010). After the United States pulled out of Laos in 1975, HMong fled to Thailand (Lee \& Tapp, 2010), and ultimately many were resettled as refugees in western countries such as the United States, Australia, Canada, and France between 1975 and 2004 (Lee et al., 2017; Yang, 2003). HMong arrived in the United States in multiple waves across 29 years. Thus, their acculturation process (e.g., English language ability) differs depending on whether they came in the 70s versus early 2000s. Specific to the United States, HMong primarily resided in California, Minnesota, and Wisconsin (PEW Center, 2017). As refugees with little access to formal education before coming to the United States, HMong parents have limited English skills and feel ill-equipped to support their students navigating higher education (Her et al., 2019).

The purpose of the HPD was to increase HMong parents' college knowledge and provide an avenue for which they feel validated and a sense of belonging on college campuses. In return, a secondary beneficiary of the event is HMong students whose parents would be equipped and empowered to support them more effectively in college. The event originally targeted HMong parents who have a child in college and did not understand English or do not use English as a primary language. However, central to HMong collectivism value, when one person is invited from the community, all are invited (L. Vang, 2015). This resulted in other HMong parents attending the event who had a child in high school as they expressed a desire to gain college knowledge to effectively prepare their child for college. The event focused on HMong parents' processes as they support their children in college. HMong parents are often left out of university programming due to their limited English ability and thus felt they could not engage in their child's educational process (Gloria et al., 2017). The HPD events were steeped in cultural interactions, provided exclusively in the HMong language, and sought to honor the role of HMong parents within their child's educational journey, particularly as they are consistently a primary source of educational encouragement for HMong students (Lor, 2008; Supple et al., 2010). Across the three HPDs, a total of 94 parents (i.e., 32, 27, and 38 attending each event, respectively) participated. Most of the parents (i.e., approximately $86 \%$ ) had at least one child in college, and the remaining $14 \%$ had at least one child in high school or younger.

\section{Guiding Conceptual Framework for Educational Programming}

Each of the activities, interactions, and processes for the HPDs were directed by a theoretical approach to ensure effective and culturally-relevant collaboration with HMong parents. Taking a contextualized person-environment approach, the research team implemented the psychosociocultural (PSC) framework (Gloria \& Rodriguez, 2000). The approach addresses three interrelated dimensions (i.e., psychological, social, and cultural) to understand students' 
educational experiences. Emphasizing the non-cognitive elements of students' experiences and ongoing processes to negotiate the educational settings (Castellanos \& Gloria, 2007), the dimensions address self-beliefs (psychological), connections and relationships within and outside of the educational setting (social), and values and worldviews that are held and challenged (cultural) within the context of higher education. The approach was originally developed for Latinx students; however, given that it is conceptualized as a meta-model, it has also been used with other diverse ethnic and racial undergraduates in assessing their educational experiences. For example, the dimensions have individually and collected predicted HMong American (Lin et al., 2015; Sengkhammee et al., 2017), Chinese American (Guan et al., 2020), and Indian American (DeVitre et al., 2021) undergraduates' educational experiences.

Extending the model from students to the student's parents, the approach has been similarly applied with Latina/o parents (Castellanos et al., 2016) and HMong parents (Her \& Gloria, 2016; Her et al., 2019) to assess the dimensionality of their roles and interactions for and with their child(ren)'s education. That is, the dimensions of self-beliefs, relational connections, and values and worldviews are similarly considered for parents as they engage the postsecondary process for and with their child(ren). For HMong parents, their sense of self-efficacy, educational expectations and connections, and cultural values relative to their encouragement of their child to earn a higher education were evidenced (Her \& Gloria, 2016; Her et al., 2019). As such, the activities planned for HPDs were guided by the PSC model. Activities addressing parents' sense of efficacy and role within their child's education stemmed from the psychological dimension. Activities focusing on parents' connections to others and within the campus setting were from the social dimension. Lastly, the cultural dimension directed activities relative to the university's honoring parents as core to their child's educational success. As the entire event, from planning to debrief, produced findings and insights, we address the event sequentially, within theoretical constructs, and levels of learning. Throughout this structure, we provide supporting rationale and tie it to our overarching theoretical approach and integrative event planning and implementation (see Figure 1). We also address how it extends the literature and learning for community-based engagement for students in higher education (Field et al., 2006). Prior to discussing the findings, we provide an overview of the contexts in which HPD took place and overview the positionality of the scholars who implemented the event.

\section{Figure 1}

Psychosociocultural Approach to HMong Parent Day

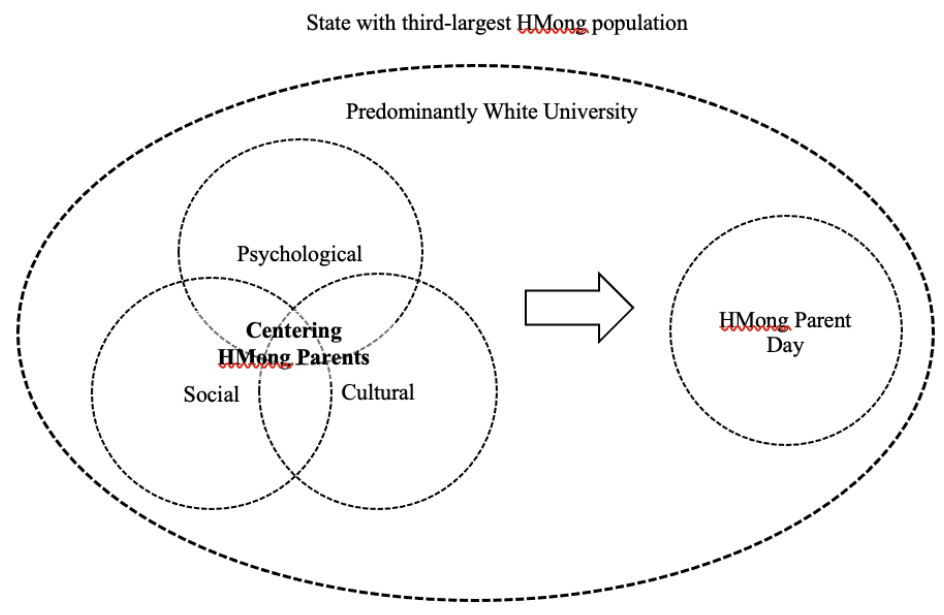




\section{Considering the Multiple Contexts of HPD: Setting the Stage}

Important to the process was considering the multiple and, at times, competing contexts for HPD. In particular, the HMong community and educational history and relationship to the university setting and structure warrants consideration. Likewise, HMong cultural values and the role of the research team are addressed to provide a culturally-relevant foundation for HPD.

\section{Community and Educational Background}

HPDs took place at a public predominantly white research university in a state with a large HMong population. HMong are the largest Asian ethnic group in the state, accounting for approximately $36 \%$ of individuals identified as "Asian or Asian American" (Gecewicz et al., 2015). From 1990 to 2010 , the HMong population has nearly tripled, from approximately 16,000 to 47,000 people (Gecewicz et al., 2015). According to the American Community Survey, $73.1 \%$ of HMong individuals between 18 and 21 years old in the state were enrolled in college in 2010, with 11.9\% holding a bachelor's degree and 2\% with a master's or higher degree (Xiong, 2012). Although HMong remain among those Asian ethnic groups in the United States with the lowest educational attainment (de Brey et al., 2019), their college enrollment rates have doubled between 2001 and 2010 (Xiong, 2012). In 2001, 11.8\% of the total HMong population enrolled in college compared to $24 \%$ in 2010 (Xiong, 2012). Current research for HMong in the state indicates HMong students are largely the first in their families to attend college, have high financial need, and lack curricula and programming specific to their cultural heritage and language (Smolarek et al., 2019). As firstgeneration college students, HMong American undergraduates often rely on their HMong college peers and siblings to provide academic support that their parents cannot (Gloria et al., 2017; Sengkhammee et al., 2017). Although HMong parents have a strong desire to support their children, they often lack the familiarity and understanding of higher education systems (Her \& Gloria, 2016; Her et al., 2019). The increasing presence of HMong in higher education throughout the United States and within the state clearly evidences a strong need for university systems to work in tandem with HMong communities for their educational advancement (Smolarek et al., 2019).

\section{Cultural Values}

Knowing and integrating HMong cultural values are of utmost importance in planning and implementing the HPD events. HMong collective culture system is based on family and clanships, providing a biological and social structure of connections (Moua, 2003). Many HMong individuals placed a high value on family and a sense of community (Her, 1998). HMong tub txawj ntxhais ntse (educated men and women) are expected to "give back" and are responsible for advancing the HMong community (Gloria et al., 2017). In honoring the role of the family and community in students' educational success, the HPD events build upon the notion of rau siab and response to the call from the community. Rau siab is the central cultural notion of "never give up" or "to keep trying or going" and is often translated as "to work hard." Rau siab is highly valued and respected and a means of interaction within HMong communities; thus, a cornerstone of the day in acknowledging and honoring the parents (Her et al., 2019).

Rau siab as the key element of the event, the connections of family and clan (familial lineage) as well as community interests needed to be clearly tied into all events and interactions. 
The intentionality of familial names on name tags, introductions, and bringing in current students as speakers served to highlight HMong cultural knowledge and values, creating culturally meaningful spaces and interactions critical to the program. Doing so allowed the HMong communities (e.g., parents, students, clan elders) to see and know themselves within the context of a predominantly white higher education space (Museus et al., 2016). Specifically, the cultural specificity of the programming conceptually and theoretically grounded in an integration framework is warranted to guide institutional efforts for HMong student success (Xiong, 2020). Also, the consistent validation of the parents as key stakeholders of their child's educational success was, in combination, important practices to hosting successful HPDs.

\section{University Setting}

The university where the HPDs took place was a large midwestern research-intensive predominantly white institution. Students of color comprised approximately $15.6 \%$ of the campus undergraduate population on campus, with Asian American undergraduates being the largest racial-ethnic minority groups. More specifically, Asian Americans were approximately four to five percent of the total undergraduate population. Identified separately are Southeast Asian Americans (reported as individuals of Laotian, Cambodian, or Vietnamese heritage for purposes of campus diversity initiatives) who included approximately 500 students per year (i.e., 516, 511, and 551, respectively) during the time of the HPDs (Office of Registrar). More broadly, the Southeast Asian students were represented across all majors, with the largest proportion represented in the College of Letters and Sciences (Office of Registrar). Although anecdotal, it was generally estimated within the HMong student community that approximately 300 to 350 HMong students were on campus. There was also formalized programming for parents/families to visit campus; yet, it was not specific to HMong cultural processes, and all university programming has only been offered in English.

\section{The Research Team}

The research team consisted of 17 members. All members, except for the faculty lead, identified as HMong or HMong American. Seven were undergraduate students, seven were master's students, and two were doctoral students at the time of these events. They represented multiple areas of study (e.g., Asian American Studies, Counseling Psychology, Educational Leadership and Policy Analysis, Human Development, Social Welfare). The team provided a unique and supportive academic context where the members served as social and cultural resources and support to conduct research under the mentorship of more advanced graduate students and a faculty advisor. The team held the assumption that the HPDs would advance HMong parents to learn more and feel more confident in their role to support their children within and/or into higher education. The team met multiple times post-event to debrief and discuss the HPD events, allowing for the team to name salient experiences of notable feedback and reactions from parents, student volunteers, university staff, and guest presenters. The team lead took informal notes that were identified as experiences to maintain, change, and/or add for future HPDs. In particular to different activities (e.g., student panels), a member of the research team took notes regarding parents' questions as a means to integrate the information via conversations in subsequent discussions and/or presentations. Also, as the research team had follow-up tasks for the event, there were 
multiple opportunities to relay reactions from the participants and presenters and memo further our reactions and experiences.

\section{Centering Hmong Parents Role on Campus}

Critical to HPD's overall success was creating a safe space that parents felt welcomed, valued, and respected (psychological) where they could establish meaningful social connections with others in their specific community (social) and implement specific emic-based values (cultural). Centering the cultural value of rau siab within each of these dimensions was key to ensuring the parents knew, felt, and were valued as having a role on campus. It is critical to acknowledge the vital role that HMong parents play in the educational success of HMong undergraduates and honor their involvement in the day-long activities that were steeped in HMong culture. As the maintenance of HMong values and language rituals directly informs HMong student educational success (Her \& Buley-Meissner, 2006; L. Vang, 2015), it was critical for the research team to show how cultural values and practices were central to and seamlessly included throughout the day. To do so, all informal and formal interactions occurred in HMong as all team members (with exception of one) spoke HMong. From greeting parents at the parking garage to leveraging cultural practice in honoring parents, the day events allowed parents and students to make "physical cultural connections" or "to connect with people from similar cultural backgrounds on campus" (p. 494), within their native language, which in turn allows for "epistemological cultural connections" or allowed them "to acquire knowledge about their own cultural communities" (Museus et al., 2016, p. 494).

\section{Greeting and Welcoming HMong Parents onto Campus}

Being invited onto campus is a critical event, particularly as they had been to campus to drop off/pick up their children yet never been inside a campus building (Gloria et al., 2017; Her et al., 2019). As one of the first times that the parents had been on campus for an event, the main focus was to engage in culturally expressive and relevant activities that would welcome parents. Parents were greeted at the parking garage and directed to a prepaid parking spot by event volunteers who spoke HMong. At the event, parents were given a printed nametag with fathers' npe laus (community known-name vs. legal name) and mothers' npe hluas nkauj (birth name vs. community known-name), escorted to a table, and invited to have breakfast. The decision to include parents' community known-name vs. Legal name is to demonstrate the nuance of cultural value associated with naming and a sign of respect within the HMong community. The specific interactions of greeting, naming, and expressed appreciation for attending the event to the HMong parents was a purposeful and proper greeting, which expressed hospitality to respect, honor, be courteous, and show humility for HMong parents and elders (C. T. Vang, 2016). The activities were strategic to ensure that parents felt valued, respected, and appreciated. In particular, the activities engaged and emphasized their role in their child's educational success, familial, and home-training practices that are frequently overlooked and left out of educational discourse (Delgado-Bernal, 2002).

Parents were also formally welcomed by prominent university administrators who emphasized the critical importance of HMong parent's support of their child's educational success. For these prominent welcomes, we employed university translation services (i.e., headphones) for parents to listen to the welcome in HMong. Involving university officials to greet the parents 
established that the larger university supported the event and emphasized that they were part of the university and not "just one-time guests." The event similarly provided university officials a space to engage closely with the HMong community and learn about their needs.

\section{Creating a Place for HMong Parents at the University}

Given the collectivistic nature of many HMong individuals (Her, 1998), the research team sought to provide a contextually relevant space for parents to express their pride for their child(ren) in higher education in a humble yet celebratory way. Parents were given the opportunity to introduce themselves and their child (e.g., name, major, educational plans); however, many parents spoke about all their children (who varied in age and school status). As a result, the HMong parents shared how they were more broadly thinking about college for all their children and seeking to be prepared as best possible (Her et al., 2019). The space allowed parents to create a sense of community and a sense of belonging by knowing others who shared a similar rau siab process in supporting their child(ren). Creating this community was important for the parents, particularly those with children not yet in college. These parents participated in the day's event to learn and want more information about the college process. The event served as a rare chance to obtain information that would better prepare them to support all their children's education, whether in college or on track for college (i.e., elementary to high school students). Recognizing the importance of relational interactions based on age, gender, and language with HMong participants is necessary.

To further create a space of belonging, each HPD was commemorated with professional photos at key campus locations. Parents posed for a parent/family photo, set against a university mascot banner, as part of the welcome. Pictures were taken in front of the main administrative building, the Graduate School, and on the steps of the newly-renovated building where the event took place. After each HPD, an $8 \times 10$ professional photo was sent to each set of parents/parent along with a hand-written thank you card in HMong. We expressed gratitude for their wisdom and guidance in providing a path to success for HMong youth and affirmed that they had a place on campus. While on campus, parents expressed feeling important to the research team members as two HMong photographers (one female and one male) captured their lived experiences on campus in photos. Throughout the day and after the event via clan relationships, familial relationships based on having the same last name, the research team was informed that the parents felt excited, appreciated, and valued as experts having received their photos at their home. Important to knowing this information were the strong clan and familial relationships and ongoing communication.

\section{Leveraging Cultural Practices to Honor HMong Parents}

Although HPD was built upon HMong cultural practices and values, two main events highlighted this process. The first practice was to invite HMong parents and students to a family-style luncheon. A home-cooked meal to connect familiar foods with their identity as HMong parents was a process consonant to HMong experience (Vue et al., 2011). Likewise, to enhance the feeling of family on campus, their undergraduate children and those on the student panels were invited to join the parents for lunch. Students were receptive to the invitation, and many joined the parents for lunch. Although we could not invite all HMong students to the lunch, many attended via word of mouth and were welcomed and joined table conversations. Parents were eager to share the 
resources they learned with their children and other HMong students at their table. Parents asked the students about their experiences on campus and showed interest in learning more about how they can better support the students' education. The research team members visited tables, offering to bring more food and drink to parents, who noted that students seemed receptive to the conversations and were opened to sharing with the parents. Students indicated that they were delighted to see parents on campus and expressed pride that the parents were stepping out of their comfort zone to participate in the event.

During lunch, parents also got to know each other through familial lineage and eat lunch catered by one of the local family HMong restaurants. Parents commented on how serving zaub tsuag, a traditional boiled vegetable dish, represented knowing the importance of HMong culture and honoring the parents' identity and wisdom. Parents encouraged the research team to pursue higher education as a means to navigate the "American world" better. However, they asked the research team and HMong students never to forget their identity. Parents saw serving zaub tsuag at a predominantly white institution as the team's ability to exist in both worlds.

The second main cultural practice was an end-of-the-day recognition ceremony that included HMong cultural practices and values. To honor rau siab, one member of the research team performed a kwv txhiaj, or sung story poem, in which she thanked the parents for their support of their children's educational process and praised them for their strength and guidance. Performing a $k w v$ txhiaj specifically evidenced oral proficiency of HMong rituals (C. T. Vang, 2016), which addressed parent's cultural wisdom to provide support through practical tasks and pab qhuas (daily words of encouragement and praise steeped in cultural notions of working hard for the greater good) (Her et al., 2019). Acknowledging the HMong parent's strength-based home processes through a $k w v$ txhiaj also evidenced the ability to merge HMong values and rituals within the university setting as well as bolstered their sense of efficacy to support their child (Her \& Gloria, 2016). Further, one of the parents responded to the $k w v$ txhiaj with a $k w v$ txhiaj of appreciation and gratitude for the day and acknowledgment and pride for HMong students who maintained their HMong culture as part of their academics. The research team members were recognized as students who used their academic knowledge to advance the community.

The ceremony involved public recognition of each parent for their rau siab, a process that has strong cultural significance (Her et al., 2019). The parents were presented with a certificate of appreciation and gifts to represent an educational ntim su. Like the traditional ntim su of preparing a gift of food for the journey home (literal translation of "to pack lunch"), the research team compiled a ntim su for the educational journey that they would take in support of their child, an action that keeps the connection of "host" and "guest" strong (C. T. Vang, 2016). Different campus partners provided university-emblem gifts (e.g., cups, pens, calendars, pins, magnets, tote bags) as well as the research team providing larger gifts (e.g., blanket, sport chair), and HMong Parent Day inscribed items (e.g., portfolio, mug). The ntim su was given as a symbol of gratitude, value, and appreciation of the parents' event attendance, wisdom, and efforts to support their child's higher education goals. Parents expressed excitement and gratitude for being part of the day. In particular, they expressed to the research team a sense of welcome and validation that what they had to offer their child was an important source of support along with the specific information and insight into the process of the university. 


\section{Emergent Knowledge from a Day of Integrated Learning: Findings and Insights}

Continued venues for HMong parent engagement at the post-secondary level are warranted as an increasing number of young HMong students are preparing to enter higher education (Gecewicz et al., 2015; U.S. Census Bureau, 2016). From the three HPD events and the rau siab (hard work) of the 94 HMong parents, the following are offered as new knowledge and insights learned from the HPD events. Throughout the day, different levels of learning occurred for the HMong parents. The first level included the physical experience of the campus spaces, whereas the second level was hearing the narrative lived experiences of Hmong students on campus. The third level included learning about and connecting with the different resources available to assist HMong students. The following activities in preparation for and implementation of the HPDs aligned with a psychosociocultural (PSC) approach (Gloria \& Rodriguez, 2000), with each activity described and supported within HMong culture and the educational literature for HMong American undergraduates.

\section{Level I: Being in the Same Space as My Child on Campus (P and C)}

Allowing HMong parents to physically be in and experience the context or setting of their child's educational lives (cultural) assisted them to bolster their sense of confidence and agency as having a central role (psychological). HMong parents place a high value on their children earning a higher education because many did not have formal education from their homelands of Laos or Thailand (Her \& Gloria, 2016; Ngo, 2008). As the path out of poverty, HMong parents are highly invested in providing practical activities (e.g., cooking, cleaning, transportation; Her et al., 2019; Lor, 2008) and emotional support (Her et al., 2019) for their children. Thus, providing them access to core educational locations (i.e., classroom, library, and residence hall) and subsequent experiences were needed as the first level of learning. Having parents engage in their students' educational environment and setting allowed them to be immersed in their student's college experience and gain insight into daily college life by being in the physical spaces and experiencing campus settings.

\section{Sitting through a classroom lecture}

Allowing parents insight into what a classroom lecture might look and feel like, an instructor provided a 15-minute lecture on an upper-division class concept in English. The parents sat through the lecture and commented that they did not realize how fast-paced and overwhelmed their child might feel if they did not understand the core idea and how disconnected they might feel from other students. Many parents expressed that the lecture experience helped build their confidence to understand some of their children's challenges by way of not understanding the class content. The instructor met the HMong parents and indicated that the experiences provided insight into HMong students' educational experiences and thus would inform subsequent teaching plans regarding engaging with HMong students.

\section{Touring the library}

Many HMong students spend time studying and even socializing at campus libraries (Gloria et al., 2017), allowing parents to know about the different resources and services created connections to key campus stakeholders. Parents toured a library, learning about study rooms, open study areas, computer labs, café, and available support staff. Parents were also provided with a handout of the 
layout and description of library resources (e.g., Writing Center) in HMong and English for future reference. Parents expressed being pleased with the available resources for their child and noted the importance of having a visual image of where their child spent their time, particularly when their children spent late nights on campus. HMong undergraduate volunteers were available to answer follow-up questions from parents regarding how they utilized library resources, such as reserving and renting books, laptops, and other supplies. Students also identified quiet study areas and group study areas and explained when they utilized those different studying spaces.

\section{Visiting a residence hall}

Many HMong parents want their children to stay close to home when attending college, particularly daughters (Ngo \& Leet-Otley, 2011). As HMong daughters who chose to live in the residence halls face criticism from the larger HMong community (Lee, 1997), it was important for parents to see what living on campus might entail. Parents visited one of the well-known oncampus residence halls, viewing a residence room, facilities, and cafeteria. A HMong student resident provided the tour, showing the parents her room and talking about her experiences and the benefits of living on campus. The mothers were most concerned about the availability of food during the tour. Food for HMong mothers represents the wealth of support and love they have for their children, and one way they can contribute to their children's education (Her et al., 2019). The parents saw a free-use shared-kitchen in the residence hall that provided cooking pots and pans. Parents were curious and expressed relief to see the living and study spaces, eating areas, and amenities for students. After seeing the living accommodations, many HMong parents indicated that they would want the opportunity to live on campus, if they were students. This tour provided them insight into the advantages of living on campus and increased perspective when their children asked to live on campus, an activity identified as useful to HMong student success (F. Vang, 2015). A mother of an incoming student said that if it were possible, she would switch places with her child so that she could go to college now, having seen different college settings.

\section{Level II: Hearing Narratives of HMong Students' Educational Experience (P, S and C)}

Hearing first-hand the educational narratives of Hmong students' educational experiences is a dimensionalized process of beliefs, social connections, and cultural processes. Importantly, the parents heard from students who were not their own children but from others who they held community pride and broad-scale investment (Her, 1998). It was through this second level of learning that allowed parents interactional engagement with the students via the student panels. Undergraduate and graduate students shared their personal and educational journey with parents and invited parents into a discussion about the intersectionality of identity, culture, and the education system. In these discussions, parents heard first-hand narratives of what it was like to be a HMong college or graduate student and gained insights in understanding their child's experiences.

\section{Engaging with undergraduate students}

A panel of six to eight HMong undergraduates from the university who represented different personal (gender, marital status) and educational (student standing, major) backgrounds presented their educational experiences based on a short series of PSC questions. A gender balance of student

presenters was sought as educational issues differ for HMong males and females at the secondary (Lo, 2017) and postsecondary levels (Her \& Gloria, 2011; Xiong, 2012). After the panelists shared 
their narratives regarding their academic study, involvement in student organizations, and future plans, parents eagerly asked them questions such as "How does getting a higher education benefit or meet the needs of your family?" and "What are your greatest difficulties as a college student?" The panelist provided a range of responses and perspectives that parents could apply with their children, particularly as parents wanted to know how students maintained cultural traditions and values while pursuing an education - a concern among HMong parents seeking to maintain cultural language and values for their children (Yang, 2008).

\section{Interacting with graduate students}

In that only four percent of HMong in the United States hold an advanced or professional degree (U.S. Census Bureau, 2016), a graduate student panel was included. The panelists again varied in background to show that continued school was accessible and obtainable regardless of status (e.g., married HMong female with children). The panelists shared their personal narratives and addressed the critical role of parental and familial support in their ongoing education and successful graduate school progress. The parents expressed their pride to the panelists, asking that they establish connections beyond the HMong community and integrate their advanced knowledge to support the HMong community. Many parents stated knowing their key role to support their child to consider graduate school. They wanted to know what else they could do to assist their child in pursuing advanced training as they asked, "What motivated you to continue more school?" and "What are your aspirations?" These questions represented the parents' understanding of their role in supporting their HMong students' educational endeavors.

\section{Level III: Accessing Available Academic and Support Resources (P, S, and C)}

The third level of learning took place when parents visited and learned about the academic and support programs available to HMong students. Through learning about how to access these resources, parents gained knowledge to assist their students by knowing who or where to direct their students for academic support (social). Parents expressed pride in knowing about these resources and noted feeling prepared to guide their students in findings support to succeed in college (psychological). Parents met with staff from three academic and support programs that were culture-specific (i.e., Asian American Studies Program staff, the Academic Advising Program staff, and the Southeast Asian American Support Advisors) to acquire resources to pass on to their child(ren).

HMong students have been identified as not knowing about available resources and needed connections to negotiate the educational systems (Xiong \& Lam, 2013). Parents were provided with contact information and brochures so that they could suggest and direct their child to these resources, particularly as having a sense of belonging is critical to HMong students' academic persistence decisions (Gloria et al., 2017). Importantly, the parents expressed relief that there were resources for their child and that staff was available to provide the services in HMong as well as to have a contact person if they had follow-up questions. Parents expressed appreciation for having met the person to whom their child would engage (i.e., had a name, face, and knowledge of the support person), again underscoring the importance of cultural relationships and connections within HMong communities (C. T. Vang, 2016). Finally, parents also expressed excitement that their children could take classes in HMong about HMong customs, history, language, and culture. They voiced a strong desire to share the resources with their child as a way of retaining HMong language and traditions while also receiving an 
education, a finding consistent with understanding what it means to be HMong for university students to be change agents for their communities (Her \& Buley-Meissner, 2006).

\section{Implications from HMong Parent Days}

Based on parents' feedback and team reflections and insights from HPD, implications for activities are provided for scholars and university personnel to consider as best practices for theoreticallydriven and culturally-steeped educational programming for HMong parents and their communities. The implications included working with university offices and personnel to gain "buy-in" and support for the event. It also involved bringing and integrating core Hmong values into the higher education setting, which has historically espoused and sought to maintain individualism, competition, and structural hierarchy based on white values (Museus \& Park, 2015). As a result, negotiating divergent cultural values was key to event planning. Finally, more formally planned and increased involvement of parents as experts throughout the planning, implementation, and debriefing of the HPDs was needed. Further discussion and working examples of these implications are addressed below.

Buy-in from university offices ranged from securing finances, identifying personnel and partnership offices who could support the day, as well as assuring student campus offices that the day would not duplicate what was already being offered. In partnering with campus offices, they provided a range of monetary resources, supplies, and time (e.g., presentation of their office during the event). In particular, the team created a HMong language booklet for parents that described campus resources and offices. As all programming and informal interactions were in HMong (white dialect), interpreters were made available for those events with non-HMong speaking presenters, except for the classroom lecture, to ensure that parents understood all conversations and knew that their language and culture were important. Working to schedule upper-level administrators (e.g., Deans, Associate Chancellor) to address HMong parents required professional persistence and negotiation of scheduling for both their schedule and what was best for the HPDs. Buy-in also meant securing continuous financial support for similar HMong parents' events. After the events, the research team learned that there were HMong parents who wanted to attend a second time despite the research team seeking to invite those who had not yet attend given limited funding. This parental desire for more time on campus underscored the need for ongoing and formalized financial support.

Next, the integration of HMong cultural values of family and community, and rau siab, throughout HPDs was essential. From engaging in formal ceremonial recognition to respectful interactions, knowing the importance of values integration and nuanced processes was needed. For example, the process of inviting HMong parents required a series of ongoing communications. First, HMong parents were invited by mail to participate. A month before each event, HMong parents were also called, and phone conversations were carefully negotiated to extend an invitation again. Considered cov hluas (the youth) of the HMong community, the research team respectfully engaged parents' cultural response to the invitation (e.g., "we'll see, we'll come if there are no other commitments"). They acknowledged that parents' responses were not disinterested but rather a culturally-engaged way of responding (i.e., not immediately saying no to keep relationships; C. T. Vang, 2016). The team also engaged in a cultural process of inviting by calling multiple times and assuring the parents that their presence would be valued, respected, and appreciated at the event (C. T. Vang, 2016). This process was key to the research team being culturally persistent with the invitations and engendering trust with the team as "university representatives." The 
research team also negotiated gender dynamics. Female team members invited the mothers, who talked with the fathers about event attendance, HMong cultural processes consonant to other HMong community events (Collier et al., 2012).

Important to the invitation process was asking a well-known HMong parent to make phone calls to speak on behalf of the research team, assuring other HMong parents, who had been invited to the event, that the day would be substantive and respectful. These "cultural brokers" (Collier et al., 2012, p. 83) were critical to building trust and served to connect the university and community. It is recommended to establish key community connections with HMong elders to "spread the word" and vouch for the event. Also, involving individuals who can honor and engage niam txiv txoj kev txawj ntse (HMong parents' wisdom) at the outset and throughout the programming is critical as the first interaction was critical for parents to know that they would be engaged with cultural proficiency.

Finally, formally asking HMong parents who participated in the event to assist in recommending the event to other parents would also prove helpful and align with the value of community working to advance the community. Formalizing the role of parent liaisons for educational programs would serve to engage and inform parents more broadly and fully. As the parents were vocal about their experiences and made suggestions throughout the days' activities, coordinating a parent feedback session for university personnel (e.g., diversity committees, academic advisors, program administrators, faculty) could prove useful. This practice would allow university stakeholders to have direct feedback and direction from HMong parents about needs and recommendations in supporting HMong students, a process that underscores that HMong parents have much to offer (Her et al., 2019). Likewise, establishing an ongoing HMong parent/community advisory panel in which HMong cultural practices and messages (e.g., rau siab) are implemented into programming and teaching can serve as the basis for developing community partnerships to engage student learning (Her et al., 2019). Such parent and community engagement could provide an opportunity for colleges and universities to establish the trust needed to develop a HMong Parent Partnership Committee and programs in best support of HMong parent educational collaborations. Likewise, universities would do well to support students and faculty to create a HMong research team or scholarship council to engage ongoing community-based engaged work on college campuses. Although it was important for parents to see the campus and learn about what the university had to offer, it was equally if not more important for the parents to feel that they had expert knowledge to offer the university and were key to their child's success.

\section{Conclusion}

The benefits of a culturally-centered community-focused intervention like HPDs are multi-fold. First, the event directly benefited HMong parents, providing them space and setting to learn about their child's college process. By bringing parents onto campus, HPDs welcomed parents into their child's educational environment and provided them a unique opportunity to partake in similar learning activities as their students. In this way, HPD provided a space for parents to learn through participation and interactive engagement. The notion of learning as a form of participation allowed parents to be active members of the knowledge being constructed about college (Rogoff et al., 2003).

Second and closely related, HMong parents acquired the college knowledge needed to support their college children. The events provided new knowledge about the college process and centered cultural values and practices as essential to HMong students' educational success. Parents 
were taught to embrace their cultural contribution to their students' success. In turn, HMong American college students indirectly benefitted from HPDs. Moreover, community-based events represent the university's effort to include and acknowledge the important presence of HMong American students on college campuses by honoring their cultural identity and formally recognizing their parents' contribution towards their educational successes. Thus, the events support HMong college students' non-persistence decisions as cultural identity serves as a protective factor against HMong college students' dropout (Gloria et al., 2017).

Finally, the community-based intervention of HPDs serves as an example of civic engagement for students, staff, and faculty to connect academic inquiry with community services. Civic engagement is a reliable pedagogical strategy for developing students' knowledge and skills and contributes to college students' learning and increased graduation rates (Cress, 2012). Students who engaged in civic engagement learn more academic content because they shifted from knowledge receivers to idea creators (Cress, 2012). Likewise, HMong parents were idea creators in learning how to best support their child in higher education.

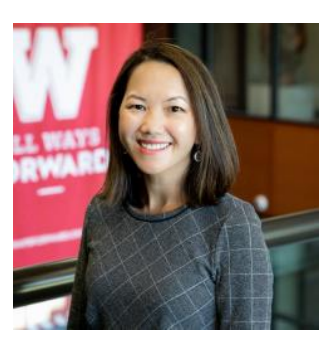

\section{About the Authors}

$\mathrm{Pa} \mathrm{Her}$ is a clinical assistant professor of counseling psychology at the University of Wisconsin-Madison. She also serves as the Assistant Director of the Counseling Psychology Training Clinic and supervises masters and doctoral students to be culturally competent clinicians. Her research focuses on Hmong and BIPOC students' educational persistence, social class experiences, and familial support and involvement.

Alberta M. Gloria is a professor of counseling psychology and an affiliate faculty member in the Chican@Latin@ Studies Program and the Asian American Studies Program at the University of Wisconsin-Madison. Her research focuses on the psychosociocultural processes that facilitate academic persistence and educational wellness and wholeness for historically underrepresented and underserved BIPOC students.

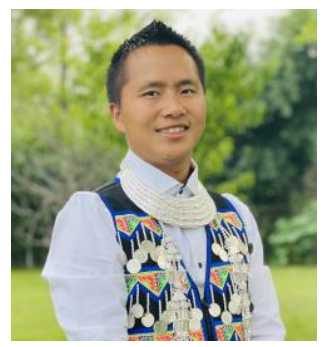

Shee Yee Chang graduated from the University of Wisconsin - Madison with a degree in Nursing and Educational Leadership and Policy Analysis. Shee Yee currently is a small business owner and serves as the Secretary of the Chang Council of Milwaukee Wisconsin.

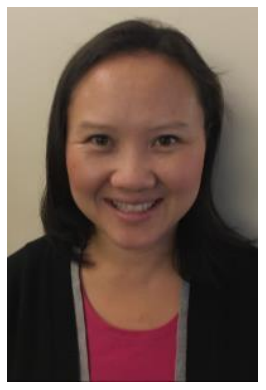

Pahoua Thao serves the community through her work in providing mental health services and in bridging opportunities with BIPOC students and families to attain their dream of earning a college degree. She mentors BIPOC young professionals in behavioral health, aiming to increase diversity and leadership within and amongst the communities. Pahoua graduated from the University of Wisconsin-Madison with degrees in Community Leadership and Counseling Psychology. 


\section{Notes}

1. Rau Siab means to work or study hard. The authors give special thanks to Maimoua Xiong, Michelle Xiong, and Rose Yang for their support and contribution to all three HPDs. The authors also recognize Saengthong Douangdara, Chou Yee Ngue Her, Douachong Lee, Mai Kao Lor, Mayta Lor, Ker Thao, Pade Thao, Hnub Vang, and Pa Tou Vue, for their assistance with individual HMong Parent's Days.

Funding for the HMong Parent's Days was secured from grants from the Kemper Knapp Bequest Committee, Office of Diversity and Campus Climate, Office of Undergraduate Recruitment and Retention, Multicultural Student Center, Asian American Studies Program, Southeast Asian American Student Academic Services, and Department of Counseling Psychology at the University of Wisconsin-Madison.

The HMong Research Team extends sincere appreciation to the many UWMadison offices that donated gifts for the educational ntim su, university personnel who gave generously of their time to talk with the parents about their offices and services provided, and student volunteers and photographers whose commitment to advance the HMong community was ever-present throughout the entire parent day. It is only with the support and guidance of the HMong community and elders that the HMong Parent's Days and ongoing research on HMong in higher education have been possible. Thank you/Ua tsaug.

2. The term HMong, capitalizing the " $\mathrm{H}$ " and " $\mathrm{M}$ " is used to increase inclusivity of Green and White HMong dialects.

\section{References}

Castellanos, J., \& Gloria, A. M. (2007). Research considerations and theoretical application for best practices in higher education: Latina/os achieving success. Journal of Hispanic Higher Education, 6(4), 378-396. https://doi.org/10.1177/1538192707305347

Castellanos, J., Gloria, A. M., Herrera, N., Kanagui-Muñoz, M., \& Flores, C. (2013). ¡Apoyamos la educación de nuestros hija/os!: How Mexican parents' college knowledge, perceptions, and concerns effect their parental support of their child. The Journal of Latino-Latin American Studies, 5(2), 85-98. https://doi.org/10.18085/1las.5.2.8xn051203217v35g

Collier, A. F., Munger, M., \& Moua, Y. K. (2012). Hmong mental health needs assessment: A community-based partnership in a small mid-western community. American Journal of Community Psychology, 49(1-2), 73-86. https://doi.org/10.1007/s10464-011-9436-z

Cress, C. M. (2012). Civic engagement and student success: Leveraging multiple degrees of achievement. Diversity and Democracy, 15(3), 2-3.

Dalton, J. H., Elias, M. J., \& Wandersman, A. (2001). Community psychology: Linking individuals and communities. Wadsworth/Thomson Learning.

de Brey, C., Musu, L., McFarland, J., Wilkinson-Flicker, S., Diliberti, M., Zhang, A., Branstetter, C., \& Wang, X. (2019). Status and trends in the education of racial and ethnic groups 2018 (NCES Report No. 2019-038). U.S. Department of Education, National Center for Education Statistics. https://nces.ed.gov/pubsearch/pubsinfo.asp?pubid=2019038 
Delgado-Bernal, D. (2002) Critical race theory, LatCrit theory and critical raced-gendered epistemologies: Recognizing students of color as holders and creators of knowledge. Qualitative Inquiry, 8(1), 105-126. https://doi.org/10.1177/107780040200800107

DeVitre, Z., Castellanos, J., Gloria, A. M., \& Dosaj, S. (2021). Indian American undergraduates' well-being: A psychosociocultural understanding of an emic approach to congruity of values. Journal of Diversity in Higher Education. Advance online publication. http://doi.org/10.1037/dhe0000302

Field, L., Elliott, M. S., \& Korn, P. R. (2006). A successful community-based intervention for addressing college student depression. Journal of College Student Development, 47(1), 105-109. https://doi.org/10.1352/csd.2006.0005

Gecewicz, C., Long, D., \& Veroff, D. (2015). Hmong in Wisconsin: A statistical overview. Applied Population Laboratory, University of Wisconsin-Madison/Extension. Retrieved from https://cdn.apl.wisc.edu/publications/hmong_chartbook_2010.pdf

Gloria, A. M., Her, P., Thao, B. J., Lee, D., Chang, S. Y., Thao, A., \& Aroonsavath, L. (2017). Tub txawj, ntxhais ntse: Experiences of Hmong American undergraduates. Journal of Family Diversity in Education, 2(4), 63-83. https://doi.org/10.53956/jfde.2017.106

Gloria, A. M., \& Rodriguez, E. R. (2000). Counseling Latino university students: Psychosociocultural issues for consideration. Journal of Counseling and Development, 78(2), 145-154. https://doi.org/10.1002/j.1556-6676.2000.tb02572.x

Guan, T. C., Gloria, A. M., \& Castellanos, J. (2020). Second-generation Chinese American female undergraduates: Psychosociocultural correlates of well-being. Asian American Journal of Psychology, 11(4), 246-258. http://dx.doi.org/10.1037/aap0000209

Her, M. (1998). A construct validity study of the values questionnaire using two divergent groups: Hmong and white Americans [Doctoral dissertation, California School of Professional Psychology Fresno Campus]. ProQuest Dissertations \& Theses Global. https://www.proquest.com/dissertations-theses/construct-validity-study-valuesquestionnaire/docview/304397855/se-2?accountid=13360

Her, V., K., \& Buley-Meissner, M. L. (2006). "Why would we want those students here?": Bridges and barriers to building campus community partnerships. Hmong Studies Journal 7, 1-43.

Her, P., \& Gloria, A. M. (2016). Kev txhawb siab: Hmong parents' educational encouragement of their undergraduate daughter/son. Journal of Family Diversity in Education, 2(2), 1934. https://doi.org/10.53956/jfde.2016.68

Her, P., Gloria, A. M., Chang, S., Thao, P., Lee, D., \& Xiong, M. (2019). Niam Txiv Txoj Kev Txawj Ntse: A Psychosociocultural understanding of Hmong parents support of their Hmong American undergraduates. Journal of Family Diversity in Education, 3(3), 34-61. https://doi.org/10.53956/jfde.2019.130

Lee, G. Y., \& Tapp, N. (2010). Culture and customs of the Hmong. Greenwood.

Lee, J. K., \& Green, K. (2008). Hmong parental involvement and support: A comparison between families of high and low achieving high school seniors. Hmong Studies Journal, 9, 1-27.

Lee, S. (1997). The road to college: Hmong American women's pursuit of higher education. Harvard Educational Review, 67(4), 803-828. https://doi.org/10.17763/haer.67.4.0296u12hu7r65562 
Lee, S., Xiong, C., Pheng, L. M., \& Vang, M. N. (2017). The model minority maze: Hmong Americans working within and around racial discourses. Journal of Southeast Asian American Education and Advancement, 12(2), 1-20. https://doi.org/10.7771/2153$\underline{8999.1153}$

Lee, S. C. (2007). The self-rated social well-being of Hmong college students in Northern California, Hmong Studies Journal, 8, 1-19.

Lin, M. M., Her, P., \& Gloria, A. M. (2015). Kawm ntawv qib siab: Understanding the psychosociocultural educational experiences of Hmong American undergraduates. Journal of Southeast Asian American Educational Advancement, 10(1), 1-22. http://doi.org/10.7771/2153-8999.1123

Lo, B. (2017). Gender, culture, and the educational choices of second-generation Hmong American girls. Journal of Southeast Asian American Education and Advancement, 12(1), 1-19. https://doi.org/10.7771/2153-8999.1149

Lor, P. (2008). Key life experiences contributing to Hmong Students' matriculation. Multicultural Education, 16(1), 39-47.

Moua, T. (2003). The Hmong culture: Kinship, marriage, \& family systems [Unpublished master's thesis]. University of Wisconsin-Stout.

Museus, S. D., \& Park, J. J. (2015). The continuing significance of racism in the lives of Asian American college students. Journal of College Student Development, 56(6), 551-569. https://doi.org/10.1353/csd.2015.0059

Museus, S. D., Shiroma, K., \& Dizon, J. P. (2016). Cultural community connections and college success: An examination of Southeast Asian American college students. Journal of College Student Development, 57(5), 485-502. https://doi.org/10.1353/csd.2016.0064

Ngo, B. (2008). The affective consequences of cultural capital: Feelings of powerlessness, gratitude and faith among Hmong refugee parents. Journal of Southeast Asian American Education \& Advancement, 3, 1-16. https://doi.org/10.7771/2153-8999.1100

Ngo, B., \& Leet-Otley, J. (2011). Discourses about gender among Hmong American policymakers: Conflicting views about gender, culture, and Hmong youth. Journal of Language, Identity, and Education, 10(2), 99-118. https://doi.org/10.1080/15348458.2011.563646

PEW Center (2017). Hmong in the U.S. Fact Sheet: Hmong population in the U.S., 2000-2015. Retrieved from https://www.pewsocialtrends.org/fact-sheet/asian-americans-hmong-inthe-u-s/

Rogoff, B., Paradise, R., Arauz, R. M., Correa-Chávez, M., \& Angelillo, C. (2003). Firsthand learning through intent participation. Annual Review of Psychology, 54, 175-203. https://doi.org/10.1146/annurev.psych.54.101601.145118

Sengkhammee, J. T., Her, P., Gloria, A. M., Lin, M. M., Thao, B. J., Cabinte, D. C., \& Aroonsavath, L. B., (2017). Txoj kev nsthiab: Hmong American undergraduates' perceptions of intellectual phoniness and psychosociocultural persistence decisions. Journal of Southeast Asian American Educational Advancement, 12(1), 1-19. https://doi.org//10.7771/2153-8999.1139

Smolarek, B. B., Vang, M., \& Wolfgram, M. (2019). HMoob American undergraduate students at University of Wisconsin's 4-year comprehensive colleges: Background, enrollment statistics, and graduation trends. Center for Research on College-Workforce Transitions.

Supple, A. J., McCoy, S. Z., \& Wang, Y. (2010). Parental influences on Hmong university students' success. Hmong Studies Journal, 11, 1-37. 
U.S. Census Bureau. (2016). American Community Survey 1-Year Estimates: Hmong alone. Retrieved from https://factfinder.census.gov/faces/tableservices/jsf/pages/productview.xhtml?pid=ACS_1 6_1YR_S0201\&prodType=table

Vang, C. T. (2016). Hmong refugees in the new world: Culture, community and opportunity. McFarland Publishers.

Vang, F. (2015). Barriers that impact Hmong students in post-secondary education [Master's thesis, St. Catherine University and the University of St. Thomas St. Paul]. Master of Social Work Master's Clinical Research Papers.

Vang, T., \& Flores, J. (1999). The Hmong Americans: identity, conflict, and opportunity. Multicultural Perspectives, 1(4), 9-14. https://doi.org/10.1080/15210969909539923

Vang, L. (2015). The impact of culture and acculturation on the academic achievement of Hmong American college students [Doctoral disseration, California State University]. ProQuest Dissertations Publishing.

Vue, W., Wolff, C., \& Goto, K. (2011). Hmong food helps us remember who we are: Perspectives of food culture and health among Hmong women with young children. Journal of Nutrition Education and Behavior, 43(3), 199-204. https://doi.org/10.1016/j.jneb.2009.10.011

Xiong, S. (2020). Research on Hmong American college students: A scoping review. Journal of Underrepresented and Minority Progress, 4(1), 65-84. https://doi.org/10.32674/jump.v4i1.1537

Xiong, S., \& Lam, S. K. Y. (2013). Factors affecting the success of Hmong college students in America. British Journal of Guidance \& Counselling, 41(2), 132-144. https://doi.org/10.1080/03069885.2012.713909

Xiong, Y. S. (2012). Hmong Americans' educational attainment: Recent changes and remaining Challenges, Hmong Studies Journal, 13(2), 1-18.

Yang, K. (2003). Hmong diaspora of the post-war period. Asian and Pacific Migration Journal, 12(3), 271-300. https://doi.org/10.1177/011719680301200302

Yang, T. (2008). Hmong parents' critical reflections on their children's heritage language maintenance. Journal of Southeast Asian American Educational Advancement, 3, 1-18. https://doi.org/10.7771/2153-8999.1113 


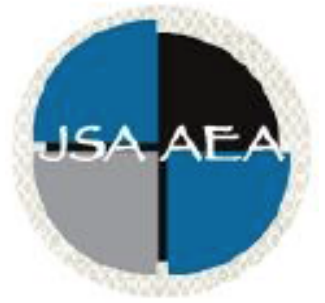

Vol.17 Iss.1 (2022)
Journal of Southeast Asian American

Education and Advancement

www.JSAAEA.org

Editor

Dr. Wayne E. Wright

Purdue University

Associate Editors

Dr. Chhany Sak-Humphry

University of Hawaii at Manoa

Dr. Phitsamay Sychitkokhong Uy

University of Massachusetts, Lowell

\author{
Book Review Editor \\ Dr. Vichet Chhuon \\ University of Minnesota \\ Creative Works Editor \\ Bryan Thao Worra \\ Lao Assistance Center \\ Journal Manager \\ Vikrant Chap \\ Purdue University
}

Editorial Review Board
Dr. Steve Arounsack

California State University, Stanislaus

Dr. Sovicheth Boun

Salem State University

Dr. Virak Chan

Purdue University

Dr. Loan Dao

University of Massachusetts Boston

Dr. Linh Dang

KIPP DC Headquarters
Dr. Carl L. Bankston III

Tulane University

Dr. Phala Chea

Lowell Public Schools

Dr. George Chigas

University of Massachusetts, Lowell

Dr. Hien Duc Do

San Jose State University

Dr. Changming Duan

University of Missouri-Kansas City 


\author{
Dr. Sophal Ear \\ Occidental College \\ Dr. Vincent K. Her \\ University of Wisconsin, Eau Claire \\ Dr. Nancy H. Hornberger \\ University of Pennsylvania \\ Dr. Peter Tan Keo \\ New York University \\ Dr. Yvonne Kwan \\ San Jose State University \\ Dr. Ravy Lao \\ California State University, Los Angeles \\ Dr. Stacey Lee \\ University of Wisconsin, Madison \\ Dr. Jacqueline Mac \\ Northern Illinois University \\ Dr. Bic Ngo \\ University of Minnesota \\ Dr. Leakhena Nou \\ California State University, Long Beach \\ Dr. Mark Pfeifer \\ SUNY Institute of Technology \\ Dr. Loan T. Phan \\ University of New Hampshire \\ Dr. Karen Quintiliani \\ California State University, Long Beach \\ Dr. Angela Reyes \\ Hunter College \\ The City University of New York \\ Dr. Fay Shin \\ California State University, Long Beach \\ Dr. Christine Su \\ College of San Mateo \\ Dr. Alisia Tran \\ Arizona State University \\ Dr. Khatharya Um \\ University of California, Berkeley \\ Dr. Kim Tran \\ University of California, Los Angeles, \\ Glendale Community College \\ Dr. Molly Wiebe \\ The University of Texas at Austin \\ Dr. Sothy Eng \\ Lehigh University \\ Dr. Jeremy Hein \\ University of Wisconsin, Eau Claire \\ Dr. Peter Nien-Chu Kiang \\ University of Massachusetts, Boston \\ Dr. Kevin K. Kumashiro \\ University of Illinois, Chicago \\ Dr. Ha Lam \\ Independent Scholar \\ Dr. Jonathan H. X. Lee \\ San Francisco State University \\ Dr. Monirith Ly \\ Royal University of Phnom Penh \\ Dr. Sue Needham \\ California State University, Dominguez Hills \\ Dr. Max Niedzwiecki \\ Daylight Consulting Group \\ Dr. Clara Park \\ California State University, Northridge \\ Dr. Giang Pham \\ University of Massachusetts Amherst \\ Dr. Malaphone Phommasa \\ University of California Santa Barbara \\ Dr. Kalyani Rai \\ University of Wisconsin-Milwaukee \\ Dr. Cathy J. Schlund-Vials \\ University of Connecticut, Storrs \\ Dr. Nancy J. Smith-Hefner \\ Boston University \\ Dr. Yer J. Thao \\ Portland State University \\ Dr. Monica M. Trieu \\ Purdue University \\ Dr. Silvy Un \\ Saint Paul Public Schools \\ Dr. Linda Trinh Vo \\ University of California, Irvine \\ Dr. Varaxy Yi Borromeo \\ California State University, Fresno \\ Dr. Yang Sao Xiong \\ The University of Wisconsin-Madison \\ Dr. Zha Blong Xiong \\ University of Minnesota
}




\title{
Doctoral Student Editorial Review Board
}

\author{
Diana Chandara \\ University of Minnesota-Twin Cities \\ Bao Diep \\ University of Minnesota-Twin Cities \\ Vanessa Sovanika Na \\ University of California San Diego \\ Khoi Nguyen \\ George Mason University \\ Hoa Nha Nguyen \\ Boston College \\ Linda Marie Pheng \\ University of Wisconsin-Madison \\ Latana Thaviseth \\ University of California Los Angeles \\ Kassandra Chhay \\ University of Minnesota-Twin Cities \\ Annie BichLoan Duong \\ San Joaquin County Office of Education \\ Nielson Hul \\ Cornell University \\ Dung Minh Mao \\ University of Minnesota-Twin Cities \\ Thien-Huong Ninh \\ University of Southern California \\ Krissyvan Truong \\ Claremont Graduate University \\ Mai Vang \\ University of Massachusetts Boston \\ Thong Vang \\ University of Minnesota-Twin Cities
}

